\title{
LIGHTNESS FACTORS AND EXERTION FACTORS RELATED TO ITS OWN MASS OF FIBER REINFORCED PLASTICS (FRP) APPLIED IN COMPOSITE AERONAUTICAL STRUCTURES (Part 2)

\author{
WSKAŹNIKI LEKKOŚCI ORAZ WSKAŹNIKI WYSIEKU \\ STRUKTURY W ODNIESIENIU DO WLASNEJ MASY \\ WEÓKNISTYCH KOMPOZYTÓW POLIMEROWYCH \\ STOSOWANYCH W STRUKTURACH LOTNICZYCH (Część 2)
}

\author{
Mirosław Rodzewicz, Jerzy Lewitowicz
}

Warsaw University of Technology / Politechnika Warszawska

Air Force Institute of Technology / Instytut Techniczny Wojsk Lotniczych

\begin{abstract}
The paper concerns an application of lightness factors in comparative analysis of strength properties of basic materials being applied in aeronautical structures - in a historical perspective. The use of lightness factors enables effective estimation how lighter will be the structural elements (of the same strength or stiffness ) made from different kind of materials : traditional as well as advanced composites. It is quite easy to find the solution to the inverse problem, i.e. to estimate how differ will be stiffness or strength for the same mass of the structural elements. Very particular application of the lightness factors are noted in engineers calculations of composite gliders wing spars, where they appears as the materials constants and as structure loading factors as well. The paper presents some examples of application of the lightness factors in strength analysis of the composite shells applied in the shear webs of the wing spars, and refers to the design recommendations issued by German aviation authority ( $L B A)$.
\end{abstract}

Keywords: aircraft, composites

Streszczenie: $W$ pracy opisano wykorzystanie wskaźników lekkości $w$ analizie porównawczej właściwości wytrzymałościowych podstawowych materiatów konstrukcyjnych stosowanych $w$ budowie płatowców $w$ ujęciu historycznym. Zastosowanie wskaźników lekkości umożliwia szybkie oszacowanie o ile lżejsze będa przy tej samej wytrzymatości lub sztywności elementy strukturalne wykonane z różnego rodzaju materiałów - zarówno tradycyjnych, jak też różnych kompozytów polimerowych. Łatwo jest również znaleźć rozwiazanie dla zagadnienia odwrotnego, tzn. oszacować ile będa różnić się sztywności lub wytrzymałości przy tej samej masie elementów strukturalnych. Wskaźniki lekkości znalazły szczególne zastosowanie winżynierskich obliczeniach kompozytowych dźwigarów skrzydet szybowców, występujac $w$ nich zarówno jako stałe materiatowe, oraz jako wskaźniki wytężenia struktury. W pracy podano przykłady zastosowania tych wskaźników do analizy powłok kompozytowych stosowanych w ściankach dźwigarów skrzydeł oraz odniesiono się do zaleceń projektowych stosowanych przez niemiecki nadzór lotniczy (LBA).

Stowa kluczowe: statki powietrzne, kompozyty 
Lightness factors and exertion factors related to its own mass of fiber... (part 2) Wskaźniki lekkości oraz wskaźniki wysitku struktury w odniesieniu... (część 2)

\section{LIGHTNESS FACTORS AND EXERTION FACTORS RELATED TO ITS OWN MASS OF FIBER REINFORCED PLASTICS (FRP) APPLIED IN COMPOSITE AERONAUTICAL STRUCTURES (Part 2)}

\section{Lightness factors as composite material constants}

There is described another benefit of usage the forces distribution instead of stresses. That is the possibility of reduction the number of strength-data regarding laminates, which are reinforced by similar fabrics having different aerial density. Table 1 presents the strength data of some glass fabrics made by the Interglas company. The thing in common for all mentioned fabrics is that they are braided from rovings having the same glass fibers (but different TEX, i.e. mass of 1000m) and have the twill weave $2 \times 2$; the fibers are distributed in almost 1:1 proportion between warp and weft.

Tab. 1 Thickness and strength properties of the laminates reinforced by some most popular glass fabrics (produced by Interglas company) absolute values

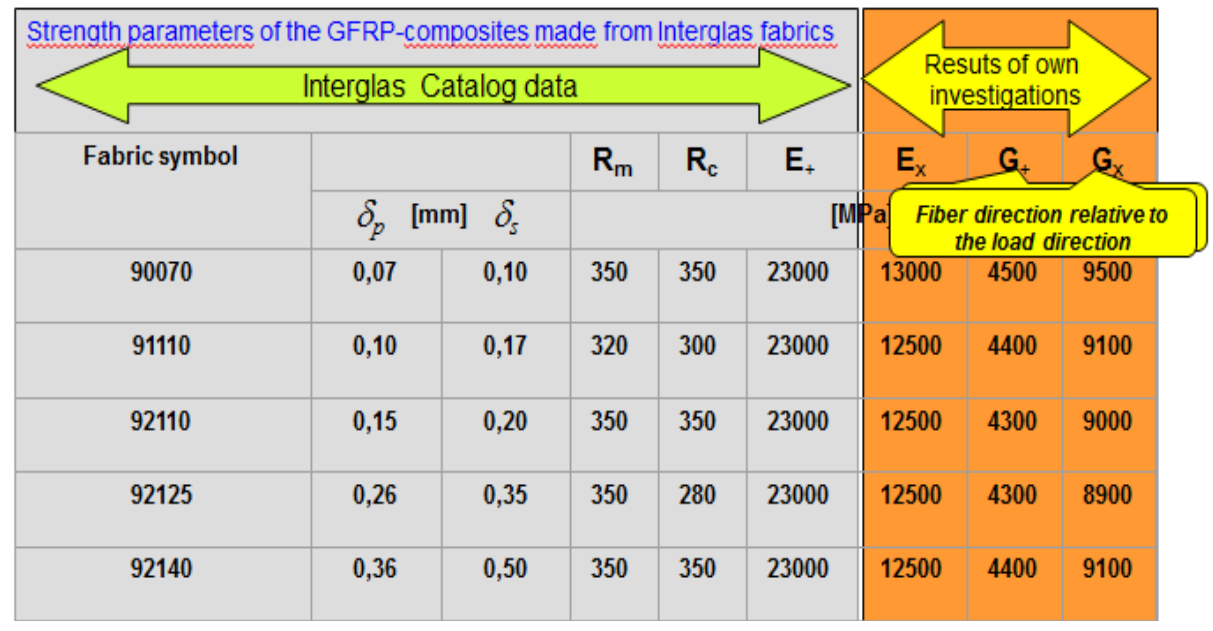

The grey zone of the table concerns the data which one can find in the catalog. The orange zone concerns data obtained from own experiments performed by the author. All strength data are in MPa. Each fabrics has own data, which make those table quite large. In order to reduce the number of this data - the first step is to recalculate the data from MPa to N/m - and to present them as, so called: unitarystrengths and unitary-stiffness. The result of this operation is presented in Table 2. 
Tab. 2 Strength properties of the laminates reinforced by some most popular glass fabrics (produced by Interglas) - unitary values (related to $1 \mathrm{~cm}$ wide strip offabric)

\begin{tabular}{|c|c|c|c|c|}
\hline Fabric symbol & $R_{m+}[\mathrm{N} / \mathrm{cm}]$ & $R_{c+}[\mathrm{N} / \mathrm{cm}]$ & $E_{+}[\mathrm{N} / \mathrm{cm}]$ & $\bar{m}\left[\mathrm{~kg} / \mathrm{m}^{2}\right]$ \\
\hline 90070 & 235 & 226 & 15696 & 0.080 \\
\hline 91110 & 314 & 284 & 22563 & 0.110 \\
\hline 92110 & 510 & 510 & 33845 & 0.161 \\
\hline 92125 & 893 & 893 & 58860 & 0.280 \\
\hline 92140 & 1275 & 1275 & 81423 & 0.395 \\
\hline
\end{tabular}

If one compare the unitary-strengths or unitary-stiffness with the aerial density of fabrics, then he discovers that they are a linear relations. This fact is illustrated in Fig. 10 using $E_{+}$modulus as an example. Those linear functions enables the reduction of the strength data to the directional coefficients of the lines representing the relation between and unitary-strengths or unitary-stiffness and the aerial density. In order to obtain the same units like in $K_{\sigma}$ case, the aerial density is multiplied by $g=9,81 \mathrm{~m} / \mathrm{s}^{2}$. As the result - we obtain $[\mathrm{m}]$ or $[\mathrm{km}]$.

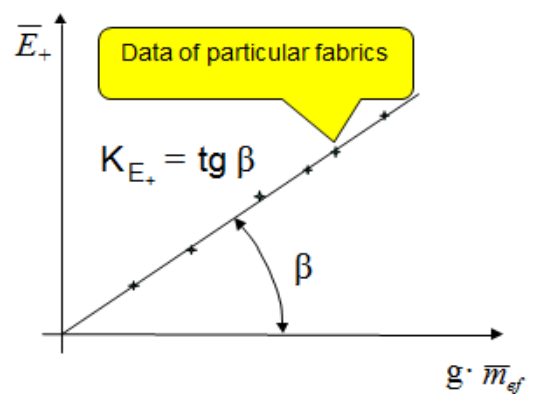

Fig. 1 Typical relation between unitary strength or stiffness and aerial density

So if we take into accounts the set of fabrics made from the same kind of fibers, and having the same weave, then the number of strength data can be reduced to the values of directional coefficients $K_{R m}, K_{R c}$, which represents the FRP endurance constants in the direction of warp fibers, and to the values of $K_{E+}, K_{E x}, K_{G+}, K_{G x}$, which represent the FRP stiffness constants on $0^{\circ} / 90^{\circ}$ or $-45^{\circ} / 45^{\circ}$ fiber lay-out. All of them comprise of specific kind of lightness factors which gives the information how many strength or stiffness can we obtain from the unit of areal density of all fabrics reinforcing the laminate. They values are collected in the Table 3.

Tab. 3 Material constants of GFRP composites reinforced by Interglas fabrics fibers EC 9 , twill weave $2 \times 2$, like in: $90070,91110,92110,92125,92140$

\begin{tabular}{|c|c|c|c|c|c|c|}
\hline $\begin{array}{c}\text { Mateial } \\
\text { constans }\end{array}$ & $\begin{array}{r}\mathrm{K}_{\mathrm{Rm}+} \\
{[\mathrm{km}]} \\
\mathrm{k}_{\mathrm{s}}=0.5\end{array}$ & $\begin{array}{r}\mathrm{K}_{\mathrm{Rc}+} \\
{[\mathrm{km}]} \\
\mathrm{k}_{\mathrm{s}}=0.5\end{array}$ & $\begin{array}{r}\mathrm{K}_{\mathrm{E}+} \\
{[\mathrm{km}]} \\
\mathrm{k}_{\mathrm{s}}=0.5\end{array}$ & $\begin{array}{r}\mathrm{K}_{\mathrm{Ex}} \\
{[\mathrm{km}]} \\
\mathrm{k}_{\mathrm{s}}=1.0\end{array}$ & $\begin{array}{r}\mathrm{K}_{\mathrm{G}+} \\
{[\mathrm{km}]} \\
\mathrm{k}_{\mathrm{s}}=1.0\end{array}$ & $\begin{array}{r}\mathrm{K}_{\mathrm{Gx}} \\
{[\mathrm{km}]} \\
\mathrm{k}_{\mathrm{s}}=1.0\end{array}$ \\
\hline $\begin{array}{c}\text { Data from } \\
\text { own } \\
\text { investigations }\end{array}$ & 42 & 41 & 3850 & 1130 & 390 & 820 \\
\hline
\end{tabular}


Lightness factors and exertion factors related to its own mass of fiber... (part 2) Wskaźniki lekkości oraz wskaźniki wysitku struktury w odniesieniu... (część 2)

In the same way was prepared the Table 4 , which concerns carbon fabrics.

Tab. 4 Material constants of CFRP composites reinforced by Interglas fabrics fibers CF 200 , twill weave $2 \times 2$, like in:. 98131, 98141, 98151

\begin{tabular}{|c|c|c|c|c|c|c|}
\hline $\begin{array}{c}\text { Material } \\
\text { constants }\end{array}$ & $\begin{array}{r}\mathrm{K}_{\mathrm{Rm}+}[\mathrm{km}] \\
\mathrm{k}_{\mathrm{s}}=0.5\end{array}$ & $\begin{array}{r}\mathrm{K}_{\mathrm{Rc}+}[\mathrm{km}] \\
\mathrm{K}_{\mathrm{s}}=0.5\end{array}$ & $\begin{array}{r}\mathrm{K}_{\mathrm{E}+} \\
{[\mathrm{km}]} \\
\mathrm{K}_{\mathrm{s}}=0.5\end{array}$ & $\begin{array}{r}\mathrm{K}_{\mathrm{Ex}} \\
{[\mathrm{km}]} \\
\mathrm{K}_{\mathrm{s}}=1.0\end{array}$ & $\begin{array}{r}\mathrm{K}_{\mathrm{G}+} \\
{[\mathrm{km}]} \\
\mathrm{K}_{\mathrm{s}}=1.0\end{array}$ & $\begin{array}{r}\mathrm{K}_{\mathrm{Gx}} \\
{[\mathrm{km}]} \\
\mathrm{K}_{\mathrm{s}}=1.0\end{array}$ \\
\hline $\begin{array}{c}\text { Data from } \\
\text { own } \\
\text { investigations }\end{array}$ & 124 & 114 & 10740 & - & 480 & 1810 \\
\hline
\end{tabular}

Note: Index ${ }_{x}$ and + refers to the orientation of the fibers.

\section{Calculation of exertion factor of FRP-shell in respect to mass of fabric used as the reinforcement}

The exertion factor of the FRP composites is sometimes used in the procedure of strength calculations of the composite gliders wing-spars. Especially it concerns the shear web of the wing spar. Let's assume for simplicity, that the role of the shear web is to carry only transversal load $T$, while the role of the spar flanges is to carry the bending momentum $M g$. Such an assumption is common in the aircraft structure design and gives safe results (i.e. a little bit over- reinforced structure of the wing spar). As the direction of the main stresses in the shear web is diagonally oriented in regard to $x$-axis - the fibers orientation of the reinforcement should be layout in the same way. Thus depending on the direction of load $T$ - on one diagonal of the square the fibers are stretched, while on the other diagonal the fibers are compressed. The exertion factor of the compressed fibers is defined by the formula:

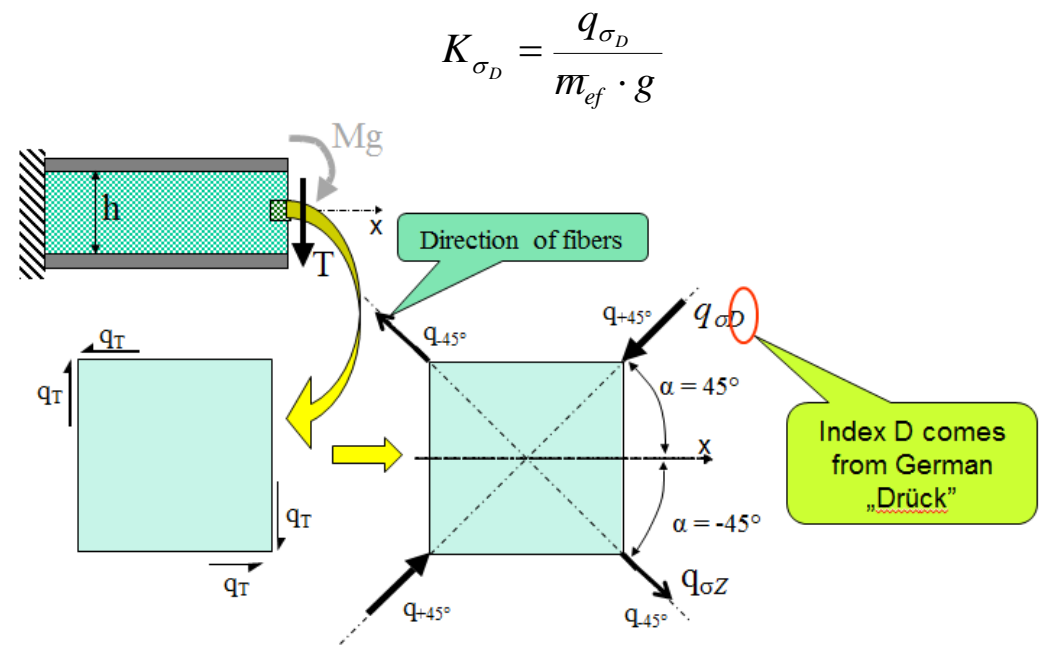

Fig. 4 Shear load and fiber orientation in the shear web of the wing spar 
Assuming that the shear web is subjected only to pure shear load - the value of $q_{\sigma D}$ can be calculated from the following formula:

$$
q_{\sigma D} \equiv q_{T}=\frac{T}{h}
$$

Note: This formula concerns the equality of numeric values of the shear force and normal force distributions along the edge or respectively along the diagonal of elementary square of the shear web (marked in Fig. 11). In next chapter (Fig. 14) one can find the justification of this equality.

\section{Applications of the lightness factor in glider structure design process}

Consistently to the fact that German engineers were the pioneers of polymer composite application in gliders technology - the first standards of composite structure design were elaborated in Germany. In 1981 German aviation authorities issued an advisory document regarding composite wing spar design. This document contains several charts, which are constructed in the way shown in the Figure 15.

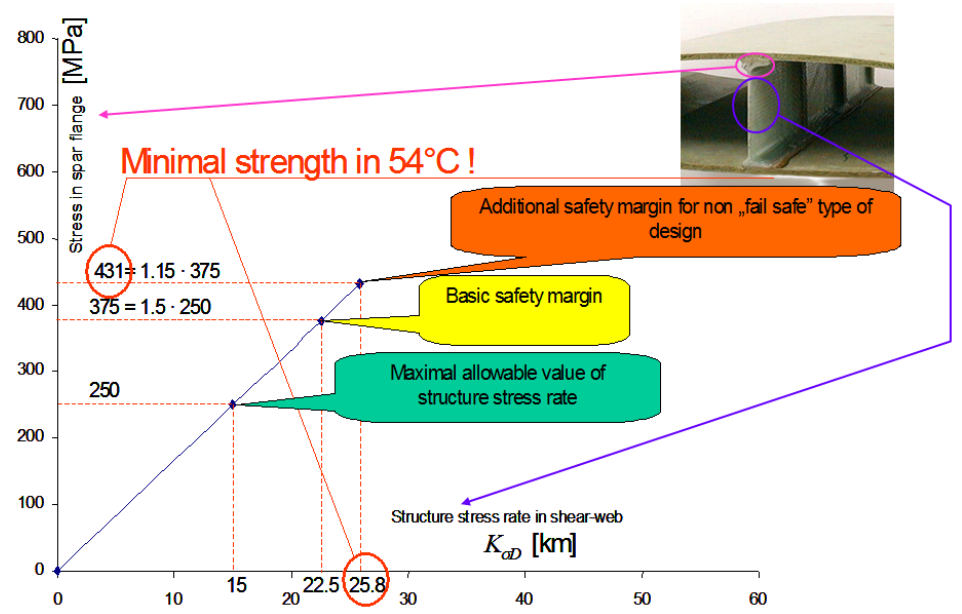

Fig. 5 Example of the advisory chart regarding composite wing spar with GFRP spar flanges and GFRP shear-web (of laminar structure) [4]

The vertical axis of the chart concerns the values of stress in the wing spar flanges, while the horizontal axis concerns the values of the structural stress rate (SSR) in a shear-web. As one can see the SSR is expressed in kilometers. On this graph there is displayed the straight line with marked 3 points.

The first (nearest to ZERO) point concerns maximal allowable values of the stresses in the wing spar flange and the SSR in the shear web of the wing-spar inside operational limit for the glider loads. The second point is shifted father by the safety factor equal to 1,5 (which is a standard value in aeronautics). 
Lightness factors and exertion factors related to its own mass of fiber... (part 2) Wskaźniki lekkości oraz wskaźniki wysitku struktury w odniesieniu... (część 2)

The most dismissed pair of points is shifted up by additional safety factor equal to 1,15 which is applied in case if there is not possible the inspection of aging processes in the structure.

The values of $431 \mathrm{MPa}$ for the wing spar flanges and $25,8 \mathrm{~km}$ for the shear web should be considered as the minimal acceptable results of ultimate strength static tests of the wing spar structure coupons. In the same way are drown up the graphs for other types of wing spars (made from GFRP or CFRP composites and having different kind of shear web structure).

\section{Example of application of the lightness factors into interpretation of experimental test results of the composite shell subjected to the shear loads}

In order to present another application of the lightness factors - there is described the experiment concerning different structures of composite shell (i.e. laminar or sandwich) subjected to the shear loads. It is commonly known that the strengthlightness factors of typical sandwich structure are very high in comparison with a laminar structure, however the loading abilities of laminate are not fully consumed in both of them. It is caused by buckling phenomenon, which in case of a laminar structure of the shell appears much earlier (depending on the thickness) than in case of sandwich structure. Significant influences on that phenomenon have physical properties of the foam core material and the relation between elastic modules of the foam core and the laminate skins.

The example of specimen, which were used in experiment is presented in Fig. 6. This is a flat composite shell in form of a square plate $200 \mathrm{~mm} \times 200 \mathrm{~mm}$. The shear load was introduced at the edges of the specimen by special 4-joints steel frame. It is assumed that all layers of fabrics used in the shells have the fibers oriented in the same direction (see Fig. 13) and thus placed optimal for carrying the applied load.

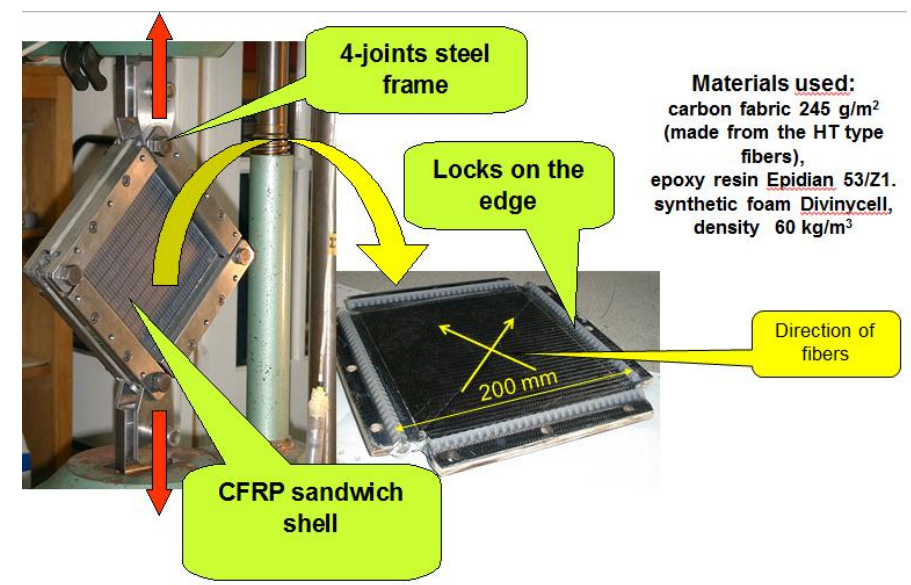

Fig. 6 View of specimen for shear loading abilities testing 
Materials used for the specimens were: carbon fabric $245 \mathrm{~g} / \mathrm{m}^{2}$, made from the HT-type of carbon fibers, epoxy resin Epidian 53/Z1. As the core was used synthetic foam Divinycell, density of $60 \mathrm{~kg} / \mathrm{m}^{3}$. The following symbols of specimens was applied: L4, L6 - specimens with laminar structure, consisting from 4- and 6-layers of fabric; S4/6, S4/8, S4/12 - specimens with sandwich structure with the core foam thickness of 6,8 or $12 \mathrm{~mm}$ and 2 layers of carbon fabrics in each skin.

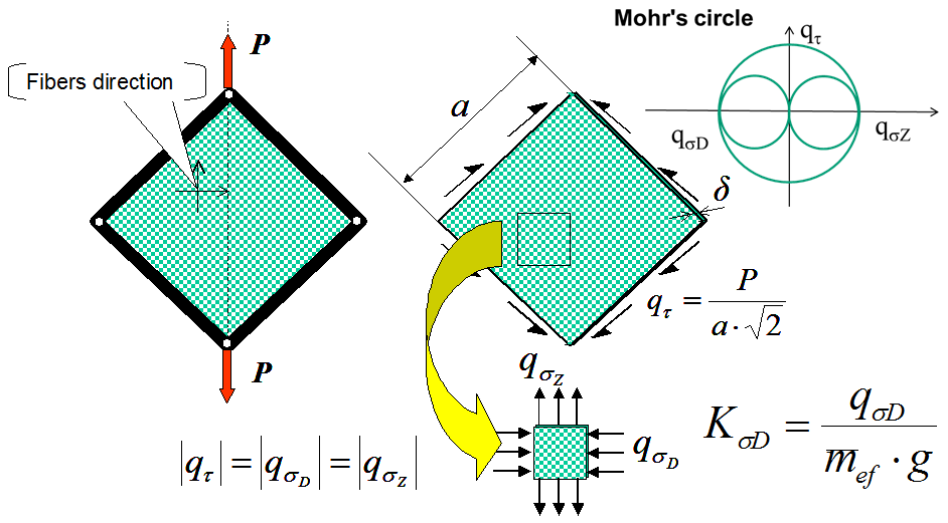

Fig. 7 Calculation of exertion factor for composite specimen presented in Fig. 6

Figure 7 contains the justification why the values load distributions $q_{\sigma}$ and $q_{\tau}$ are equal. It arises from analysis of Mohr's circles representing pure shear loading case of isotropic shell. Of course the composite material is not isotropic, but if the fibers of reinforcement are laid along directions of principal stresses orthogonally - then simply isotropic model gives sufficient accuracy.

The experiment had two aims: to measure the shear stiffness \& to test the loading abilities. Shear stiffness can expressed either by product $G_{\mathrm{x}} \cdot \delta$ or by $K_{G \mathrm{x}}$, where ${ }_{\mathrm{x}}$ is a symbol of fiber orientation in the specimen. Figure 8 contains the explanation and formulas how to derive $G_{\mathrm{x}} \cdot \delta$ value having $P$ and $x$ values.

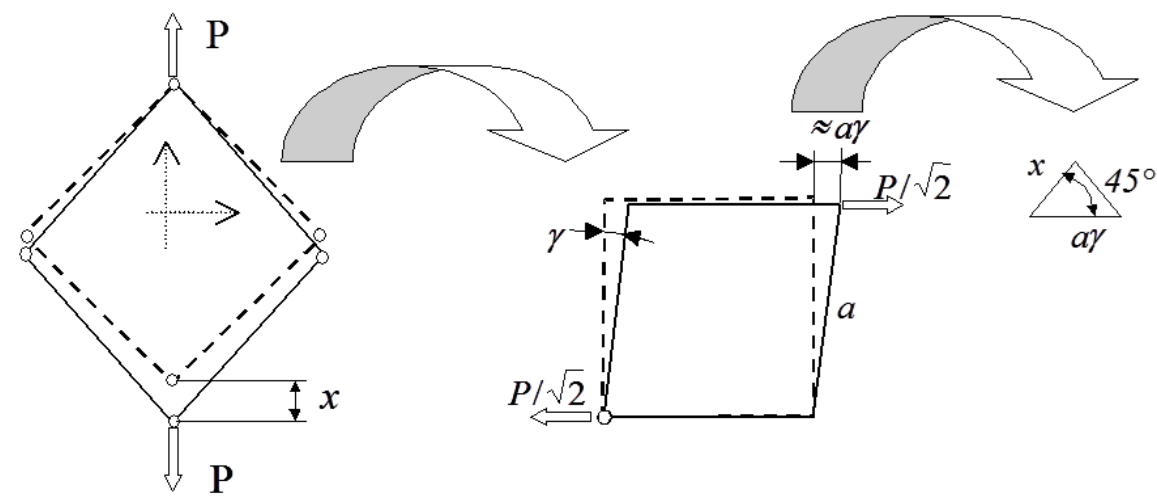

Fig. 8 Method of shear stiffness estimation 
Lightness factors and exertion factors related to its own mass of fiber... (part 2) Wskaźniki lekkości oraz wskaźniki wysiłku struktury w odniesieniu... (część 2)

$$
\begin{gathered}
\gamma=\frac{\tau}{G_{x}}=\frac{q_{\tau}}{G_{x} \delta} \\
\frac{x}{a \gamma}=\cos 45^{\circ}=\frac{1}{\sqrt{2}} \Rightarrow \gamma=\frac{x \sqrt{2}}{a} \\
\frac{x \sqrt{2}}{a}=\frac{P}{a G_{x} \delta \sqrt{2}} \Rightarrow G_{x} \delta=\frac{P}{2 x}
\end{gathered}
$$

The experiment was divided into two phases. At first the specimens were subjected to cyclic loading within range $200 \mathrm{daN} \leftrightarrows 1600 \mathrm{daN}$. That was done in order to determine the gradient of $x$ value increment resulting from the $P$ value increment, and to draw up on this basis the graph presented in Fig. 9. In the second phase the specimens were subjected to an increasing cyclic load - up to destruction. Having the results of the both phases of experiment - was drown up the graph presented in Fig. 10.

Figure 9 concerns relatively small values of the $P$-force, which were not involved the destruction of the specimens. As one can see the stiffness of laminar structures depends on the number of layers used in composite shell and significantly drops down with the load increment. In case of sandwich structures the stiffness almost not depends on load increment (increasing tendency visible in the graph is rather caused by the reduction of backlashes in the contact zones of the steel frame elements and composite plate.

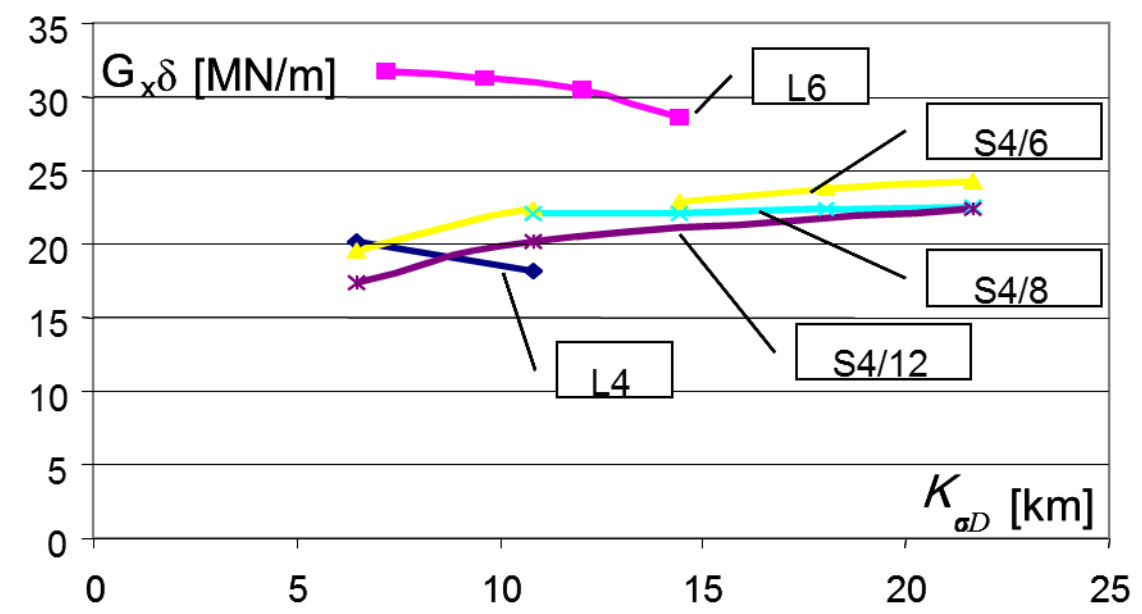

Fig. 9 Unitary shear stiffness vs exertion factor of flat composite shells with laminar and sandwich structure 
The results presented already in Fig. 9 (but recalculated from $\mathrm{G}_{\mathrm{x}} \delta$ to $K_{G \mathrm{x}}$ values) are shown again in Fig. 17. There are presented also the values of exertion factor $\mathrm{K}_{\sigma \mathrm{D}}$ in the moment of destruction (marked on the graph by the "blast" pictogram). Green arrows ended by short red line segments shows the usable limits (designated by values of destructive loads divided by safety factors $1,5^{*} 1,15$ - the same which were used in Fig. 5).

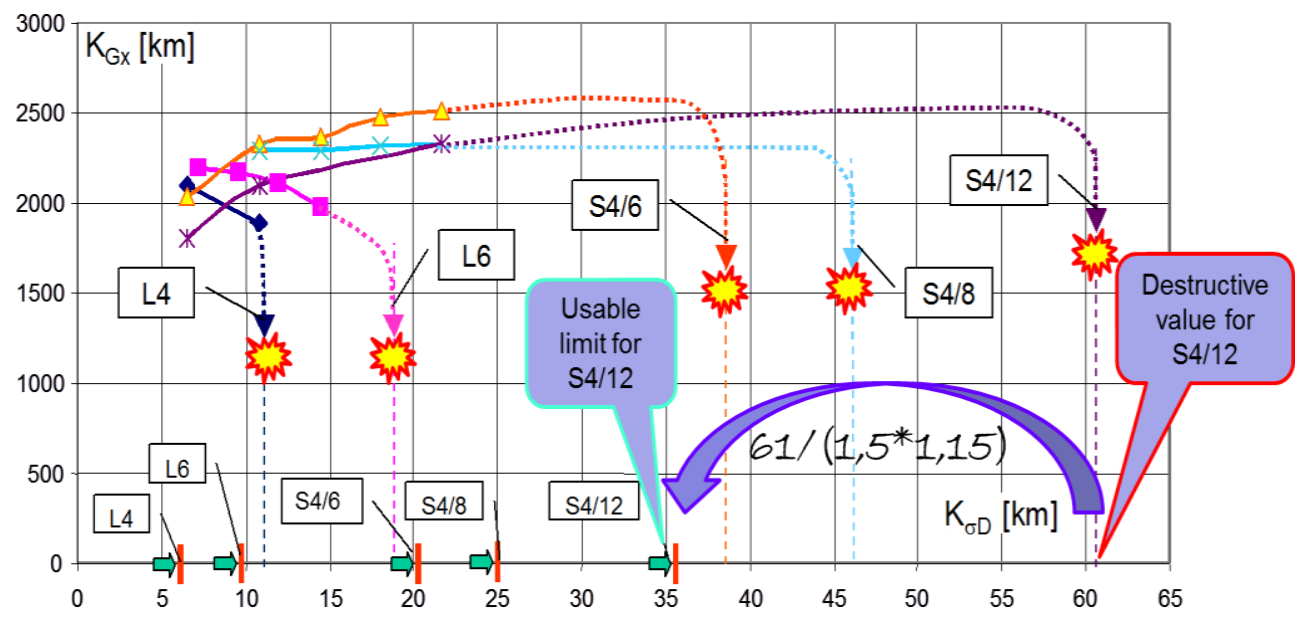

Fig. 10 Shear stiffness constants and usable limits of exertion factors for flat composite shells with laminar and sandwich structure

As it arises from Fig. 10, laminar structures of the plate can be competitive to sandwich plates only for very low values of factor $K_{\sigma D}$. For example laminar plate L6 consisted from 6 layers of fabrics, can compete in terms of shear stiffness and mass with sandwich structures $\mathrm{S} 4 / 6$ or $\mathrm{S} 4 / 8$ only up to $K_{\sigma D} \approx 8 \mathrm{~km}$.

Taking into consideration, that theoretically maximum allowable value of $K_{\sigma D}$ is $114 \mathrm{~km}$ (this is the value of $K_{R c}$ - see Tab. 3), it means that effectiveness of usage of strength properties of the reinforcement fabrics would be very low due to bucking problem (see Fig.11). In case of sandwich specimen S4/12 this effectiveness is equal to $35,4 / 114=0,31$, i.e.: $31 \%$. This result can be increased, for example by application of special reinforcement inside the foam-core (see Fig.12).

On left side of Fig. 11 is shown the plate of laminar structure; the buckling appears even when load increment is relatively low and recovers, when load is removed. As one can see - the buckling has a global nature. On the right side is shown the plate of sandwich structure; the buckling appears just before specimen destruction (when load is extremely high) and has a local nature. The deformations are accompanied by structure damages and are not recoverable. 
Lightness factors and exertion factors related to its own mass of fiber... (part 2) Wskaźniki lekkości oraz wskaźniki wysitku struktury w odniesieniu... (część 2)
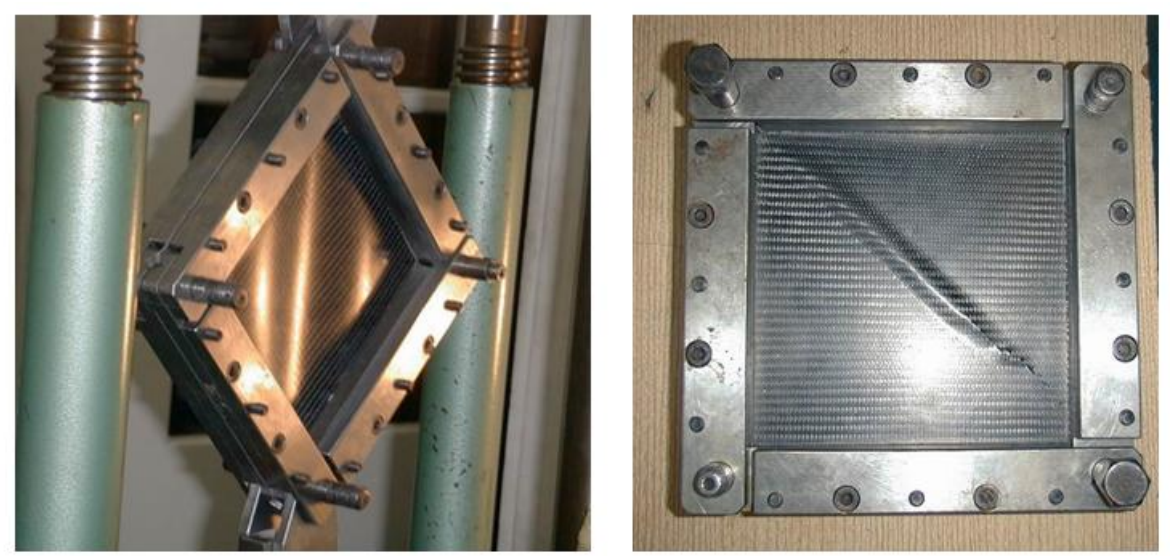

Fig. 11 Buckling of the plates subjected to the shear load

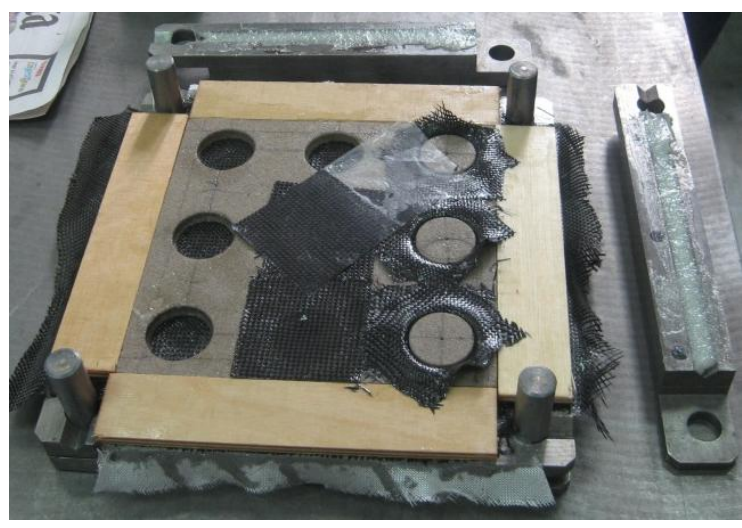

Fig. 12 Example of treatment of increasing loading abilities of sandwich structure (additional reinforcement of the foam-core)

\section{Bibliography}

[1] Jancelewicz B.: Podstawy konstrukcji lotniczych z kompozytów polimerowych, Wyd. ITWL Warszawa 2000.

[2] Kensche Ch. W.: The influence of materials on the development of sailplane design, Technical Soaring, Volume XXVTT - July 2003.

[3] Kustron K.: The design technology development of prospective airframe in view of the operation\&maintenance experience and technology development, Journal of KONBiN 2 (22) 2012.

[4] Luftfahrt - Bundesamt : Vorläufige Dimensionierungswerte für Holme von Segelflugzeugen und Motorseglern, Stand: 20. August 1981. 


\section{WSKAŹNIKI LEKKOŚCI ORAZ WSKAŹNIKI WYSIŁKU STRUKTURY W ODNIESIENIU DO WLASNEJ MASY WLÓKNISTYCH KOMPOZYTÓW POLIMEROWYCH STOSOWANYCH W STRUKTURACH LOTNICZYCH}

(Część 2)

\section{Wskaźniki lekkości jako stałe materiałowe kompozytów}

W niniejszej części opisano zaletę towarzyszącą zastosowaniu $\mathrm{w}$ obliczeniach wytrzymałościowych kompozytów metody obliczeń polegającej na posłużeniu się wydatkami sił zamiast naprężen. Chodzi o możliwość redukcji danych dotyczących parametrów wytrzymałościowych powłok laminatowych wykonanych $\mathrm{z}$ tkanin rowingowych o różnej gramaturze.

Tabela 1 zawiera dane wytrzymałościowe laminatów wykonanych $\mathrm{z}$ kilku różnych tkanin f-my Interglas. Cechą wspólną wszystkich wymienionych w tabeli tkanin jest to, że są wykonane $\mathrm{z}$ takiego samego włókna szklanego (różny jest tylko w każdej tkaninie TEX pasm rowingu, czyli masa 1000 m.b.) i mają ten sam splot krzyżowy $2 x 2$ oraz proporcję włókien wątku i osnowy równą w przybliżeniu 1:1.

Tab. 1 Grubość i wtaściwości wytrzymatościowe laminatów na bazie tkanin f-my Interglas (wartości absolutne)

\begin{tabular}{|c|c|c|c|c|c|c|c|c|}
\hline \multicolumn{9}{|c|}{$\begin{array}{r}\text { Wartości parametrów wytrzymałościowych kompoz } \\
\text { Dane katalogowe producenta }\end{array}$} \\
\hline \multirow[t]{2}{*}{ TKANINA } & & & $\mathbf{R}_{\mathrm{m}}$ & $\mathbf{R}_{\mathrm{c}}$ & $\mathbf{E}_{+}$ & $\mathbf{E}_{\mathrm{x}}$ & $\mathbf{G}_{+}$ & $\mathbf{G}_{x}$ \\
\hline & $\delta_{p}$ & $\delta_{s}$ & \multicolumn{6}{|c|}{ [MPa] } \\
\hline 90070 & 0,07 & 0,10 & 350 & 350 & 23000 & 13000 & 4500 & 9500 \\
\hline 91110 & 0,10 & 0,17 & 320 & 300 & 23000 & 12500 & 4400 & 9100 \\
\hline 92110 & 0,15 & 0,20 & 350 & 350 & 23000 & 12500 & 4300 & 9000 \\
\hline 92125 & 0,26 & 0,35 & 350 & 280 & 23000 & 12500 & 4300 & 8900 \\
\hline 92140 & 0,36 & 0,50 & 350 & 350 & 23000 & 12500 & 4400 & 9100 \\
\hline 92145 & 0,19 & 0,28 & 740 & 740 & 34000 & - & 4500 & 9100 \\
\hline
\end{tabular}

Zaznaczone na szaro kolumny w Tabeli 1 dotyczą danych, które można znaleźć w katalogu producenta tkanin. Kolumny zaznaczone na pomarańczowo zawierają dane uzyskane na podstawie eksperymentów przeprowadzonych przez autora [1]. Wszystkie dane wytrzymałościowe są tu podane w MPa. 
Lightness factors and exertion factors related to its own mass of fiber... (part 2) Wskaźniki lekkości oraz wskaźniki wysitku struktury w odniesieniu... (część 2)

Tabela jest rozbudowana $\mathrm{z}$ uwagi na to, że każda tkanina ma inne dane. Aby zredukować liczbę danych należy w pierwszym kroku przeliczyć dane z MPa na $\mathrm{N} / \mathrm{m}$ i przedstawić je jako tzw. jednostkową wytrzymałość lub jednostkową sztywność. Rezultat takiej operacji zapisano w Tabeli 2.

Tab. 2 Właściwości wytrzymałościowe laminatów na bazie tkanin f-my Interglas wartości jednostkowe (odnoszace się do $1 \mathrm{~cm}$ paska tkaniny)

\begin{tabular}{|c|c|c|c|c|}
\hline $\begin{array}{c}\text { Oznaczenie } \\
\text { tkaniny }\end{array}$ & $R_{m_{+}}[\mathrm{N} / \mathrm{cm}]$ & $R_{c+}[\mathrm{N} / \mathrm{cm}]$ & $E_{+}[\mathrm{N} / \mathrm{cm}]$ & $\bar{m}\left[\mathrm{~kg} / \mathrm{m}^{2}\right]$ \\
\hline 90070 & 235 & 226 & 15696 & 0.080 \\
\hline 91110 & 314 & 284 & 22563 & 0.110 \\
\hline 92110 & 510 & 510 & 33845 & 0.161 \\
\hline 92125 & 893 & 893 & 58860 & 0.280 \\
\hline 92140 & 1275 & 1275 & 81423 & 0.395 \\
\hline
\end{tabular}

Analizując te dane i odnosząc je do gramatury tkaniny łatwo jest zauważyć, że między jednostkową wytrzymałością (lub jednostkową sztywnością) a gramaturą tkaniny występuje liniowy związek. Fakt ten został zilustrowany na Rys. 1 na przykładzie jednostkowego modułu sztywności $E_{+}$. Istnienie tej liniowej zależności umożliwia redukcję danych $\mathrm{z}$ Tabeli 1 poprzez wprowadzenie zależności korelacyjnych i posłużenie się współczynnikami kierunkowymi prostych reprezentujących zależności jednostkowych wytrzymałości (lub jednostkowych sztywności) od gramatury tkaniny. W celu zapewnienia sobie możliwości porównania zredukowanych danych dot. wytrzymałości ze wskaźnikami wysiłku struktury $K_{\sigma}[2]$ gramatura tkanin w zależności funkcyjnej jest mnożona przez przyspieszenie ziemskie $g=9,81 \mathrm{~m} / \mathrm{s}^{2}$ (patrz Rys. 1). W rezultacie tego zabiegu współczynnik kierunkowy liniowej zależności jednostkowej sztywności lub jednostkowej wytrzymałości wyrażony jest w [m] lub [km].

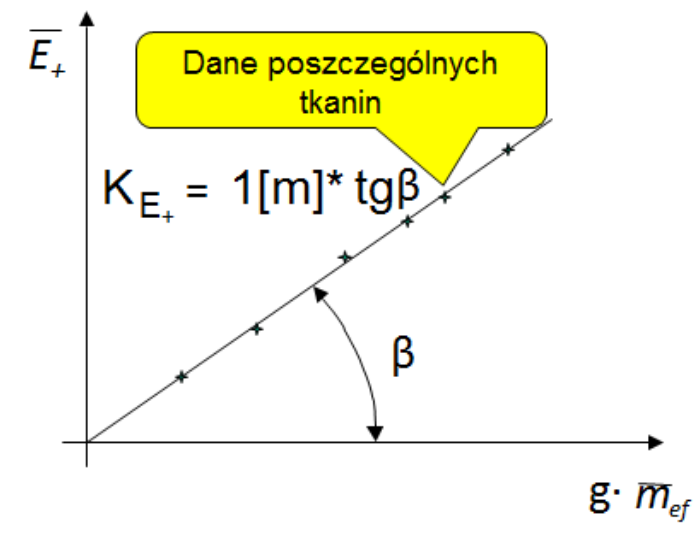

Rys. 1 Typowa zależność jednostkowej sztywności (lub jednostkowej wytrzymatości) laminatu od gramatury tkaniny 
Tak więc, jeżeli weźmie się pod uwagę wybraną klasę tkanin rowingowych utkanych $\mathrm{z}$ takich samych włókien i mających ten sam splot to wówczas liczba danych wytrzymałościowych może zostać zredukowana do zbioru wartości współczynników kierunkowych $K_{R m} \mathrm{i} K_{R c}$, które reprezentują wytrzymałość kompozytu na kierunku włókien osnowy, oraz zbioru wartości $K_{E+}, K_{E x}, K_{G+}, K_{G \times}$, które reprezentują stałe materiałowe dot. sztywności na kierunku ułożenia włókien $0^{\circ} / 90^{\circ}$ lub $-45^{\circ} /+45^{\circ}$.

Obie grupy współczynników tworzą specyficzny rodzaj wskaźników lekkości, które informują nas ile wytrzymałości lub sztywności można otrzymać z jednostki gramatury tkanin użytych w laminacie.

Wartości tych współczynników zgromadzono w Tabeli 3.

Tab. 3 Stałe materiatowe kompozytów na bazie tkanin szklanych Interglas (dotyczy rodziny tkanin z wtókien EC 9, splot rzadkowy $2 \times 2$, np. 90070, 91110, 92110, 92125, 92140)

\begin{tabular}{|c|c|c|c|c|c|c|}
\hline $\begin{array}{c}\text { Stała } \\
\text { materiałowa }\end{array}$ & $\begin{array}{r}\mathrm{K}_{\mathrm{Rm}+} \\
{[\mathrm{km}]} \\
\mathrm{k}_{\approx}=0.5\end{array}$ & $\begin{array}{r}\mathrm{K}_{\mathrm{Rc}+} \\
\quad[\mathrm{km}] \\
\mathrm{k}_{\approx}=0.5\end{array}$ & $\begin{array}{r}\mathrm{K}_{\mathrm{E}+} \\
{[\mathrm{km}]} \\
\mathrm{k}_{\approx}=0.5\end{array}$ & $\begin{array}{l}\mathrm{K}_{\mathrm{Ex}} \\
\quad[\mathrm{km}] \\
\mathrm{k}_{\approx}=1.0\end{array}$ & $\begin{array}{r}\mathrm{K}_{\mathrm{G}+} \\
\quad[\mathrm{km}] \\
\mathrm{k}_{\approx}=1.0\end{array}$ & $\begin{array}{r}\mathrm{K}_{\mathrm{GX}} \\
{[\mathrm{km}]} \\
\mathrm{k}_{\approx}=1.0\end{array}$ \\
\hline $\begin{array}{c}\text { Dane } \\
\text { z badań } \\
\text { ZSiŚ PW }\end{array}$ & 42 & 41 & 3850 & 1130 & 390 & 820 \\
\hline
\end{tabular}

W podobny sposób zostały przygotowane dane zawarte w Tabeli 4, które dotyczą laminatów na bazie tkanin węglowych.

Tab. 4 Stałe materiatowe kompozytów na bazie tkanin weglowych Interglas (dotyczy rodziny tkanin z wtókien CF200, splot rzadkowy 2 × 2, np. 98131,98141, 98151)

\begin{tabular}{|c|c|c|c|c|c|c|}
\hline $\begin{array}{c}\text { Stała } \\
\text { materiałowa }\end{array}$ & $\begin{array}{r}\mathrm{K}_{\mathrm{Rm}+} \\
\quad[\mathrm{km}] \\
\mathrm{k}_{\approx}=0.5\end{array}$ & $\begin{array}{r}\mathrm{K}_{\mathrm{Rc}+} \\
\quad[\mathrm{km}] \\
\mathrm{k}_{\approx}=0.5\end{array}$ & $\begin{array}{r}\mathrm{K}_{\mathrm{E}+} \\
{[\mathrm{km}]} \\
\mathrm{k}_{\approx}=0.5\end{array}$ & $\begin{array}{r}\mathrm{K}_{\mathrm{Ex}} \\
{[\mathrm{km}]} \\
\mathrm{k}_{\approx}=1.0\end{array}$ & $\begin{array}{r}\mathrm{K}_{\mathrm{G}+} \\
{[\mathrm{km}]} \\
\mathrm{k}_{\approx}=1.0\end{array}$ & $\begin{array}{r}\mathrm{K}_{\mathrm{Gx}} \\
{[\mathrm{km}]} \\
\mathrm{k}_{\approx}=1.0\end{array}$ \\
\hline $\begin{array}{l}\text { Rezultaty } \\
\text { badań } \\
\text { własnych }\end{array}$ & 124 & 114 & 10740 & - & 480 & 1810 \\
\hline
\end{tabular}

Uwaga: Indeksy $x$ oraz + dotycza orientacji włókien względem przyłożonego obciążenia.

Obliczenia wskaźników wysilku struktury w powłoce kompozytowej z uwzględnieniem masy tkaniny użytej jako zbrojenie

Wskaźnik wysiłku struktury powłoki kompozytowej zbrojonej tkaninami był używany $\mathrm{w}$ obliczeniach wytrzymałościowych dźwigarów skrzydeł szybowców kompozytowych. Dotyczy to w szczególności ścianek dźwigara. Aby to objaśnić przyjmijmy założenie upraszczające, że wyłączną rolą ścianki dźwigara jest przeniesienie obciążeń od siły tnącej $T$, podczas, gdy rolą pasów dźwigara jest przeniesienie momentu gnącego $M g$ (Rys. 2). 
Lightness factors and exertion factors related to its own mass of fiber... (part 2) Wskaźniki lekkości oraz wskaźniki wysitku struktury w odniesieniu... (część 2)

Takie uproszczenie jest często stosowane w obliczeniach konstrukcyjnych, gdyż daje bezpieczny wynik (tzn. lekko przewymiarowaną konstrukcję dźwigara).

Gdyby taka ścianka była wykonana z materiału izotropowego, to kierunki naprężeń głównych byłby zorientowane diagonalnie do osi podłużnej dźwigara. Zatem również w przypadku ścianki kompozytowej włókna zbrojenia muszą mieć diagonalną orientację. Zostało to zilustrowane na Rys. $2 \mathrm{w}$ odniesieniu do kwadratowego wycinka ścianki dźwigara. Zależnie od zwrotu przyłożonej siły $T-$ wzdłuż jednej przekątnej kwadratu włókna byłyby rozciągane, a wzdłuż drugiej przekątnej byłyby ściskane. Biorąc pod uwagę, że obciążenia ściskające $\mathrm{z}$ reguły wymiarują konstrukcję można wyliczyć wskaźnik wysiłku struktury z następującego wzoru:

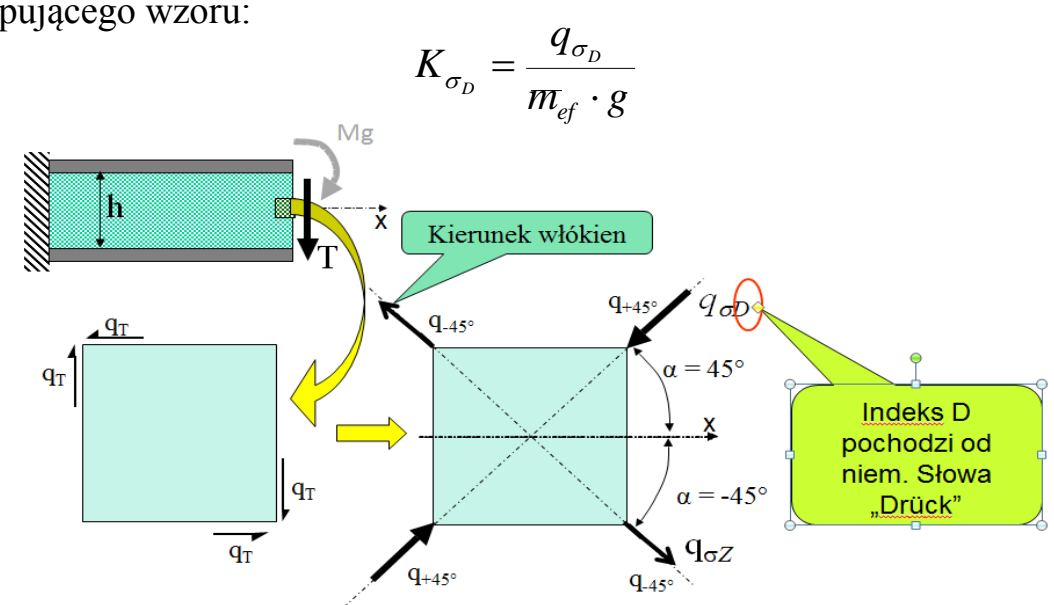

Rys. 2 Obciążenie tnace i kierunki orientacji wtókien w ściance dźwigara skrzydła kompozytowego

$\mathrm{Na}$ mocy przyjętego założenia, że ścianka dźwigara poddana jest wyłącznie ścinaniu - wartość $q_{\sigma D}$ wynosi przy tym:

$$
q_{\sigma D} \equiv q_{T}=\frac{T}{h}
$$

Uwaga: Powyższa formuła dotyczy jedynie numerycznej równości wydatków siły normalnej oraz sity tnacej odpowiednio wzdtuz przekatnej lub wzdłuż krawędzi rozpatrywanego kwadratowego wycinka ścianki. W rozdziale 3 zawarto uzasadnienie tej równości.

\section{Zastosowanie wskaźnika lekkości w procesie projektowania dźwigara skrzydła}

Konsekwencją faktu, że niemieccy inżynierowie byli pionierami technologii kompozytowej w szybownictwie jest to, że pierwsze standardy w projektowaniu struktur kompozytowych zostały opracowanie w Niemczech. W 1981 r. niemiecki nadzór lotniczy opublikował dokument z zaleceniami dotyczącymi projektowania dźwigarów skrzydeł kompozytowych [3"].

W dokumencie tym znajduje się kilka wykresów utworzonych w sposób pokazany na Rys. 3. 


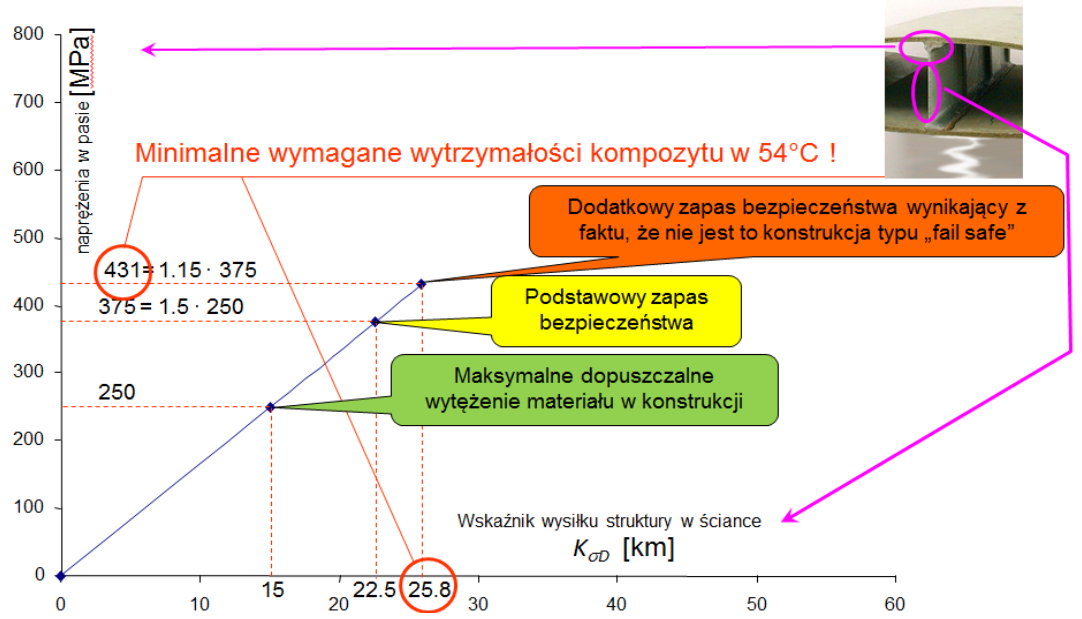

Rys. 3 Przykladowy wykres dot. Zaleceń odnośnie projektowania dźwigara skrzydta składającego się z pasów oraz ścianki z kompozytów szklano-epoksydowych [3]

Oś pionowa tego wykresu dotyczy wartości naprężeń w pasie dźwigara, natomiast oś pozioma dotyczy wskaźnika wysiłku struktury ścianki dźwigara wyrażonego w $\mathrm{km}$. Na grafie przedstawiono linię prostą z zaznaczonymi 3 punktami.

Pierwszy z tych punktów (najbliższy początkowi układu współrzędnych) dotyczy maksymalnych dozwolonych wartości obciążeń operacyjnych. Drugi punkt jest oddalony o wartość współczynnika bezpieczeństwa 1,5 (wartość standardowa w lotnictwie). Najbardziej oddalony trzeci punkt jest rezultatem uwzględnienia dodatkowego współczynnika bezpieczeństwa 1.15, który jest stosowany w przypadku braku możliwości prowadzenia diagnostyki procesu starzenia struktury. Przypisane do tego punktu wartości $431 \mathrm{MPa}$ i 25,8 km należy traktować, jako minimalne akceptowalne rezultaty badań statycznych próbek struktury dźwigara.

W ten sam sposób przedstawiono w tym dokumencie grafy dot. również innych typów dźwigarów skrzydeł kompozytowych (wykonanych z kompozytów szklanoepoksydowych lub węglowo-epoksydowych).

\section{Przykład zastosowania współczynników lekkości do interpretacji wyników badań eksperymentalnych powłok poddanych obciążeniom tnącym}

W celu zademonstrowania kolejnego przykładu zastosowania współczynników lekkości - opisano eksperyment dotyczący powłok kompozytowych zarówno laminarnych, jak też przekładkowych poddanych działaniu sił tnących w płaszczyźnie. Powszechnie wiadomo, że wytrzymałościowe wskaźniki lekkości typowej struktury przekładkowej są bardzo wysokie w porównaniu ze strukturami laminarnymi, jednakże zdolności przeniesienia obciążeń przez włókna zbrojenia nie są w pełni wykorzystane w obu przypadkach. 
Lightness factors and exertion factors related to its own mass of fiber... (part 2) Wskaźniki lekkości oraz wskaźniki wysiłku struktury w odniesieniu... (część 2)

Jest to wywołane zjawiskiem wyboczenia, które w przypadku powłok laminarnych występuje przy znacznie mniejszym obciążeniu (zależnie od grubości) niż w przypadku powłok o strukturze przekładkowej. Istotny wpływ na to zjawisko mają cechy fizyczne materiału wypełniacza struktury przekładkowej (np. pianki) i relacja między modułami sztywności wypełniacza i powłok laminatowych.

Przykład próbki użytej w tym eksperymencie pokazano na Rys. 4. Jest to płaska powłoka w formie kwadratu o boku 200 x $200 \mathrm{~mm}$. Obciążenie tnące jest wprowadzane na krawędziach próbki za pomocą specjalnej, stalowej ramki 4przegubowej służącej do wymuszenia odkształcenia postaciowego. Wszystkie warstwy tkanin $\mathrm{w}$ powłokach kompozytowych mają $\mathrm{z}$ założenia włókna zorientowane w wzdłuż przekątnych kwadratu (patrz Rys. 4), czyli są ułożone optymalnie, aby przenieść przyłożone obciążenie.

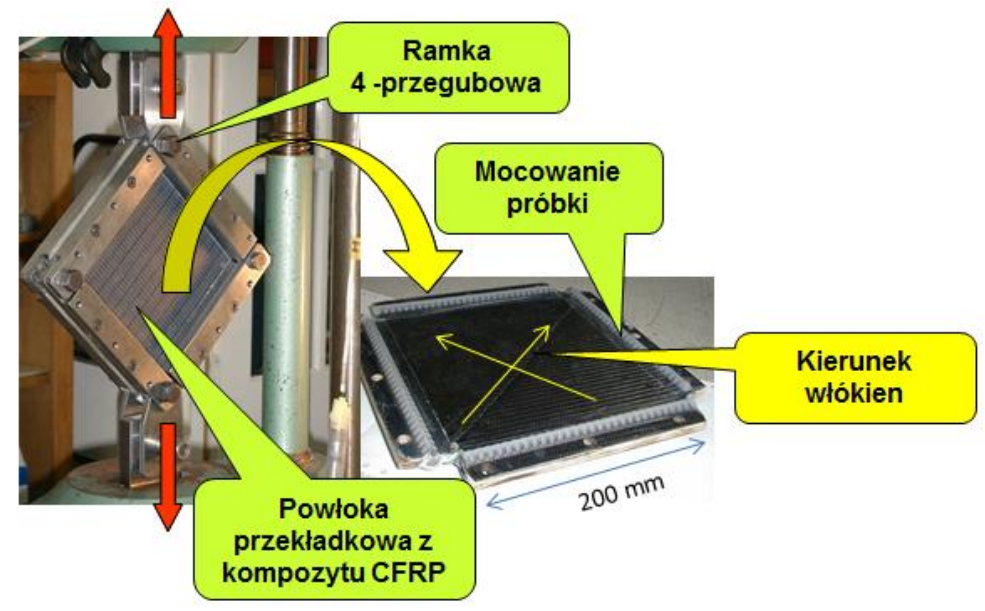

\section{Rys. 4 Widok próbki do badań zdolności przenoszenia obciążeń tnacych}

Materiały użyte do wytworzenia próbek to: tkanina węglowa $245 \mathrm{~g} / \mathrm{m}^{2}$ utkana z włókien typu HT, żywica epoksydowa Epidian 53 z utwardzaczem Z1. Jako wypełniacz użyto piankę Divinycell, o gęstości $60 \mathrm{~kg} / \mathrm{m}^{3}$.

Przyjęto następujące oznaczenia próbek: L4, L6 - próbki o strukturze laminarnej składającej się odpowiednio z 4 lub 6 warstw tkanin; S4/6, S4/8, S4/12 - próbki o strukturze przekładkowej, w której użyto pianek o grubościach odpowiednio 6, 8 lub $12 \mathrm{~mm}$ oraz po dwie warstwy tkaniny w okładkach zewnętrznych.

Rysunek 5" zawiera wyjaśnienie dlaczego wydatki obciążenia $q_{\sigma}$ oraz $q_{\tau}$ mają te same wartości liczbowe. Wynika to z analizy kół Mohr'a dla przypadku czystego ścinania powłok izotropowych. Oczywiście powłoki kompozytowe nie są materiałem izotropowym, ale jeśli włókna zbrojenia są ułożone ortogonalnie wzdłuż kierunków naprężeń głównych w powłoce izotropowej - to ów prosty model izotropowy zapewnia wystarczającą dokładność. 


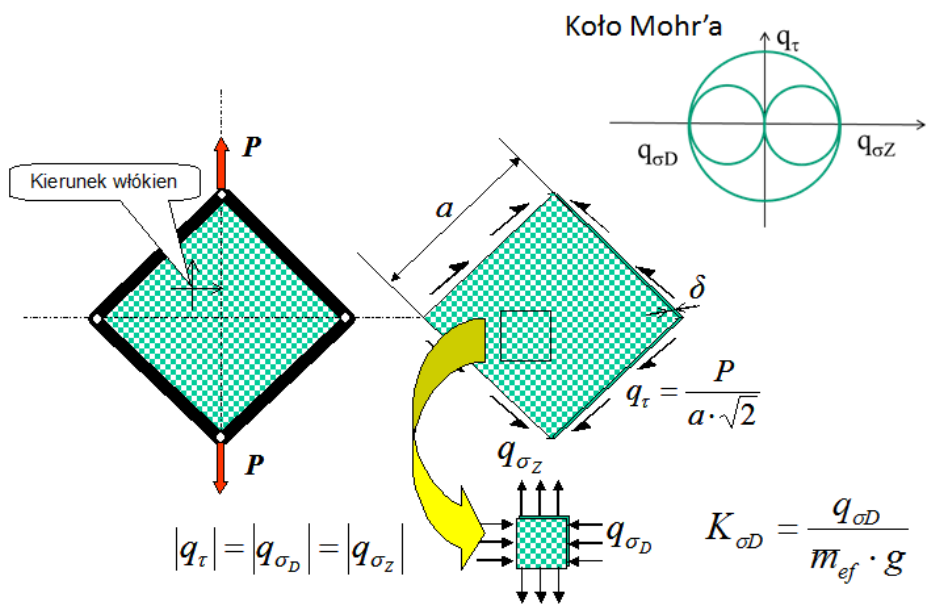

Rys. 5 Obliczenia wskaźnika wysiłku struktury dla próbki kompozytowej z Rys. 4

Eksperyment miał dwa cele: pomiar sztywności postaciowej oraz pomiar zdolności przeniesienia obciążeń. Sztywność postaciowa może być wyrażona bądź iloczynem $G_{x} \cdot \delta$ lub przez wartość $K_{G x}$, gdzie x oznacza orientację włókien w próbce. Rysunek 6 zawiera wyjaśnienie oraz wzory jak obliczyć wartość $G_{\mathrm{x}} \cdot \delta$ mając wartość $P$ oraz $x$.

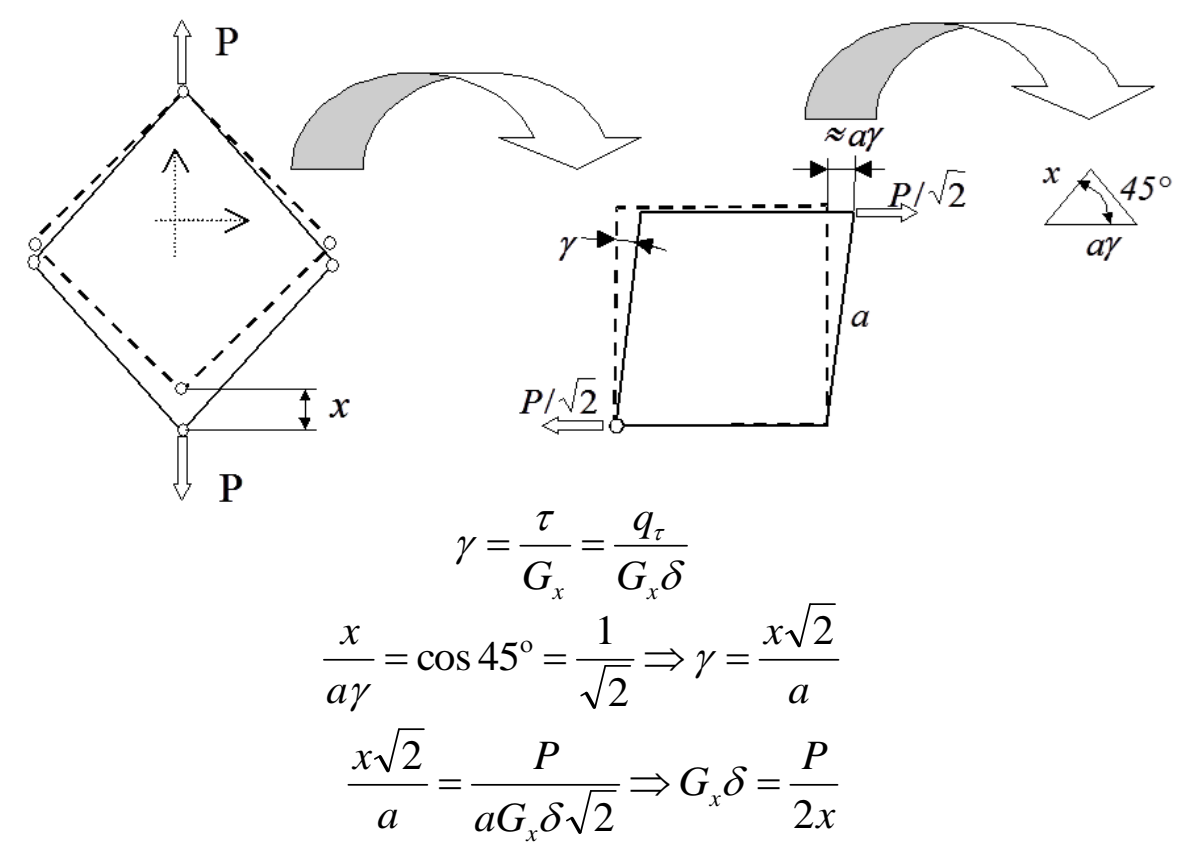

Rys. 6 Metoda estymacji sztywności postaciowej 
Lightness factors and exertion factors related to its own mass of fiber... (part 2) Wskaźniki lekkości oraz wskaźniki wysiłku struktury w odniesieniu... (część 2)

Eksperyment został podzielony na dwie fazy. Najpierw próbki poddane zostały obciążeniu cyklicznemu w zakresie $200 \mathrm{daN} \leftrightarrows 1600 \mathrm{daN}$. Zostało to uczynione celem określenia gradientów przyrostu wartości $x$ wynikających z przyrostów siły $P$ i opracowania na tej podstawie wykresów zamieszczonych na Rys. 7. W drugiej fazie eksperymentu próbki poddano narastającemu obciążeniu aż do zniszczenia. Mając rezultaty obydwu faz eksperymentu - został sporządzony graf przedstawiony na Rys. 8.

Rysunek 7 dotyczy względnie niskich wartości siły P, która nie powodowała destrukcji próbek. $Z$ wykresu wynika, że sztywność struktur laminarnych zależy od liczby warstw tkaniny użytej do wytworzenia powłok i spada ona znacząco wraz ze wzrostem przyrostu siły. W przypadku powłok o strukturze przekładkowej - sztywność niemal nie zależy od przyrostu obciążenia (widoczna na wykresach lekka tendencja zwyżkowa powodowana jest przez kasację luzów w strefie kontaktu: kompozyt-ramka stalowa).

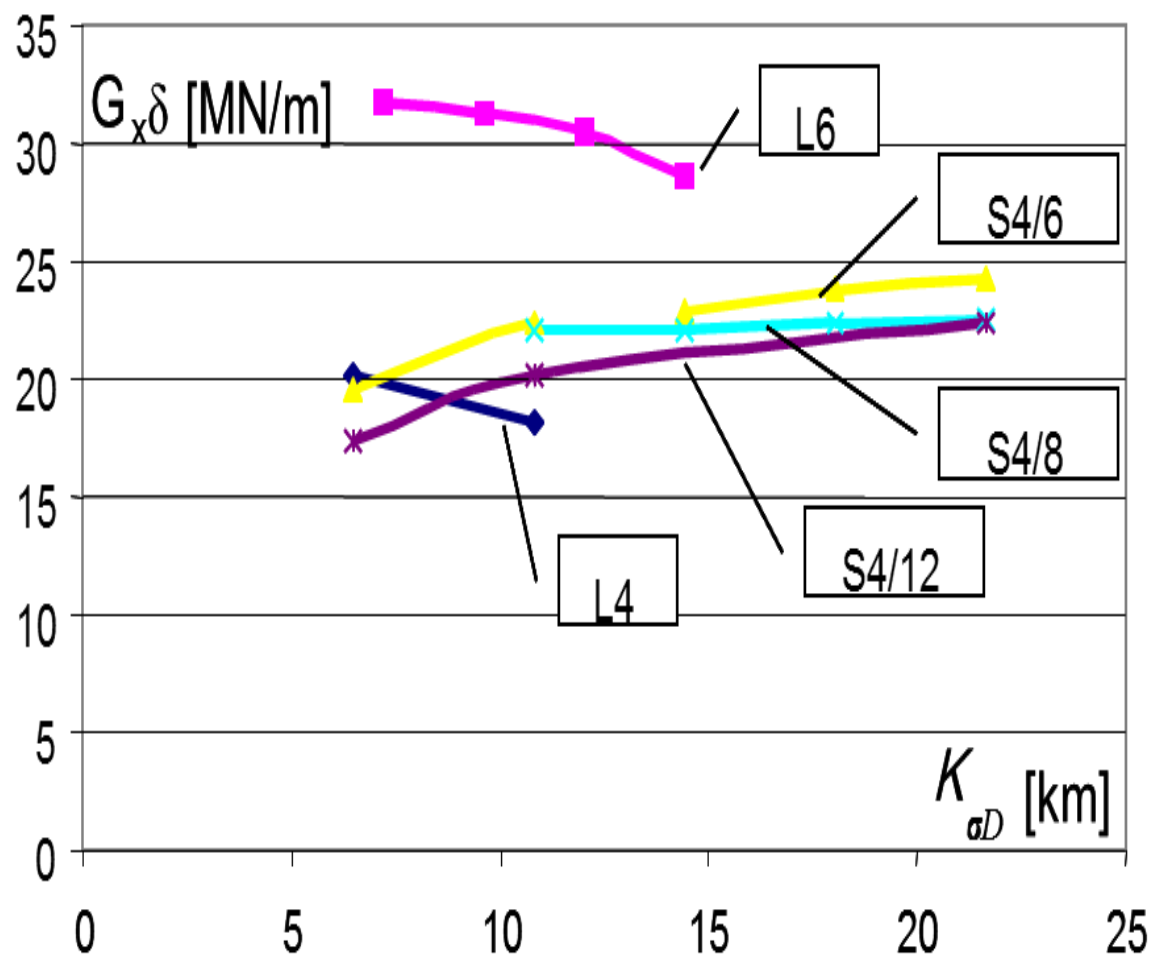

Rys.7 Jednostkowa sztywność na ścinanie w funkcji wspótczynnika wysitku struktury próbek laminarnych i próbek przekładkowych [4] 
Wyniki przedstawione na Rys. 7 (ale przeliczone $\mathrm{z}_{\mathrm{x}} \delta$ na wartości $K_{G \mathrm{x}}$ są pokazane ponownie na wykresach znajdujących się na Rys. 8 obejmujących również wyniki drugiej fazy eksperymentu. $\mathrm{Na}$ rysunku tym symbolami „eksplozji” zaznaczono momenty zniszczenia próbek i wskazano wartości współczynnika $\mathrm{K}_{\sigma \mathrm{D}}$ przy których to zniszczenie nastąpiło.

Zielonymi strzałkami dochodzącymi do czerwonych kreseczek zaznaczono zakresy użytkowe (wyznaczone przez wartości obciążeń niszczących podzielonych przez współczynniki bezpieczeństwa $1,5 * 1,15$ - czyli takich, jakie użyte były na grafie z Rys. 3).

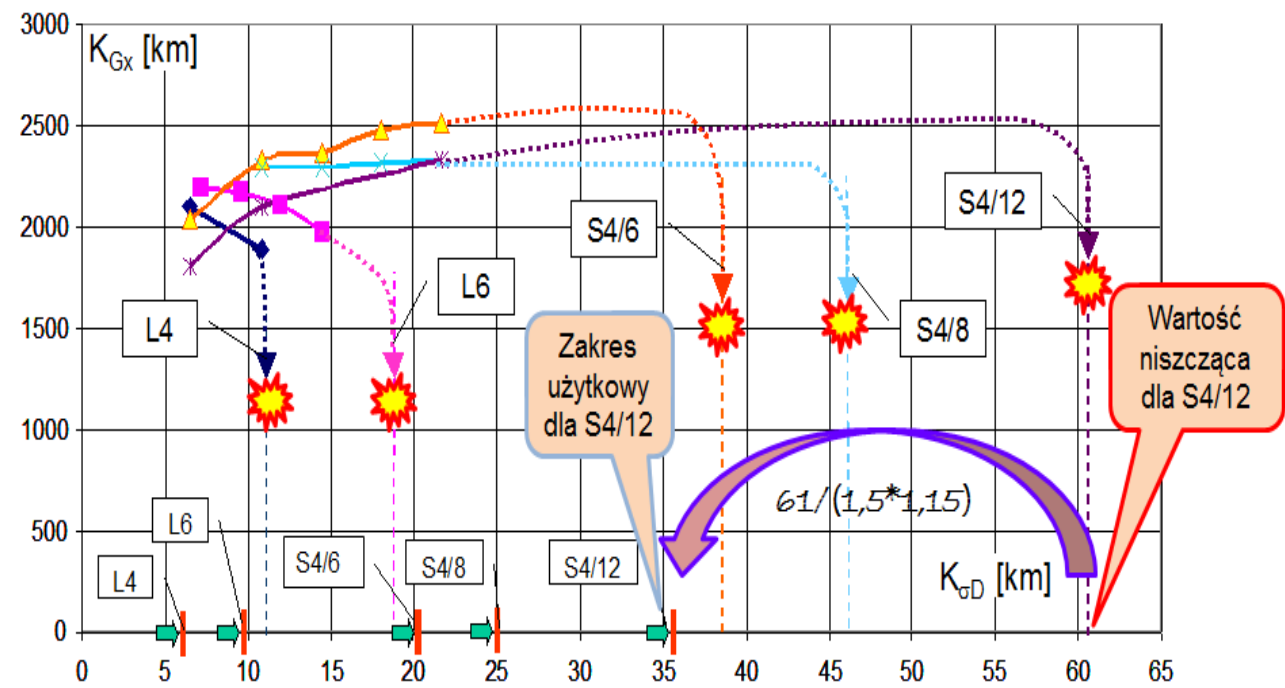

Rys. 8 Stała materiałowa odnoszaca się do sztywności postaciowej I użytkowe zakresy wskaźnika wysitku struktury dla płaskich powłok kompozytowych laminarnych lub przekładkowych [4]

Jak wynika to z Rys. 8 - laminarne struktury powłok mogą być substytutem przekładkowych struktur powłok jedynie dla bardzo małych wartości $K_{\sigma D}$. Na przykład powłoka laminarna składająca się z 6 warstw tkaniny węglowej może konkurować pod względem masy i sztywności ze strukturą przekładkową S4/6 lub S4/8 tylko do wartości wskaźnika wytężenia struktury $K_{\sigma D} \approx 8 \mathrm{~km}$.

Mając na uwadze, że teoretycznie największa wartość wskaźnika $K_{\sigma D}$ to $114 \mathrm{~km}$ (jest to wartość $K_{R c}$ - patrz Tab. 3) - oznacza to, że efektywność wykorzystania możliwości nośnych tkanin zbrojenia jest to bardzo niska z powodu problemów z utratą stateczności (patrz Rys. 9). W przypadku próbki S4/12 ta efektywność wynosi $35,4 / 114=0,31$, czyli: $31 \%$. Wynik ten może być poprawiony poprzez zastosowanie specjalnego system zbrojenia wewnątrz wypełniacza piankowego (patrz Rys. 10). 
Lightness factors and exertion factors related to its own mass of fiber... (part 2) Wskaźniki lekkości oraz wskaźniki wysitku struktury w odniesieniu... (część 2)
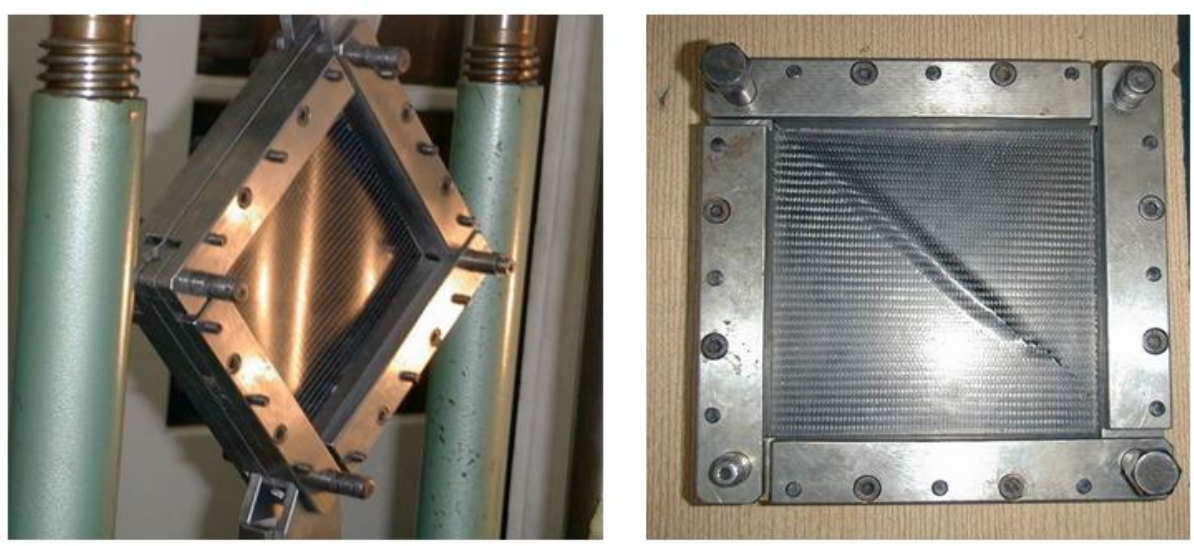

Rys. 9 Utrata stateczności powłok poddanych obciażeniom tnacym (z lewej laminarna $w$ trakcie obciażenia - z prawej przektadkowa po zniszczeniu)

Po lewej stronie Rys. 9 pokazano powłokę o strukturze laminarnej; utrata stateczności pojawia się już wówczas, gdy przyrost obciążenia jest względnie mały i zanika, gdy obciążenie jest zdjęte. Jak widać na fotografii zjawisko to ma charakter globalny. Po prawej stronie Rys. 9 pokazano powłokę o strukturze przekładkowej. Utrata stateczności pojawia się tuż przez zniszczeniem powłoki (gdy obciążenia są ekstremalnie wysokie) i ma charakter lokalny, a towarzyszące jej deformacje powłoki są trwałe.

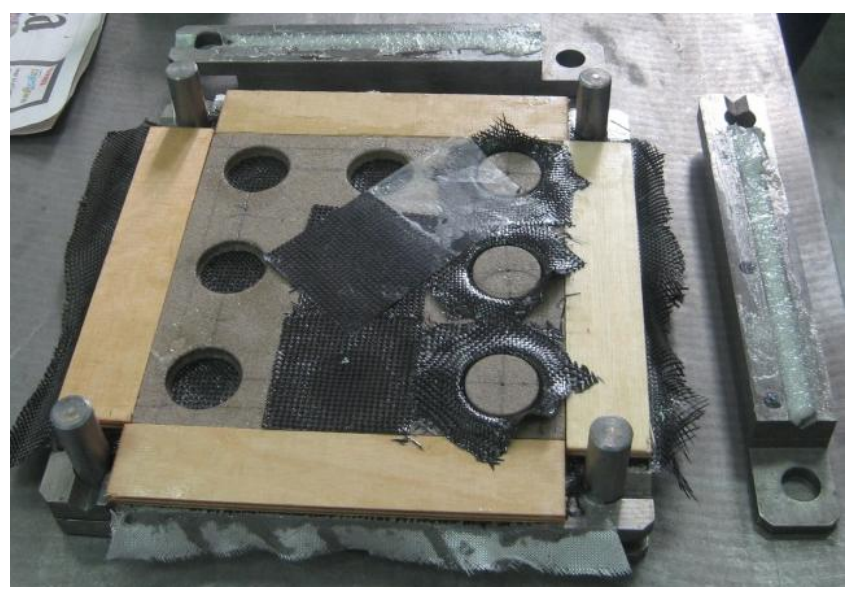

Rys. 10 Przykład sposobu zwiększenia możliwości nośnych powłoki przekładkowej poprzez zwiększenie odporności na utrate stateczności (wprowadzenie dodatkowego zbrojenia wewnątrz rdzenia piankowego) [4]

\section{Podziękowanie}

Autorzy wyrażaja podziękowanie Panu doc. dr. inż. B. Jancelewiczowi za inspirację tematyka wskaźników lekkościowych kompozytów. 


\section{Literatura}

[1] M. Rodzewicz: Why the composites? - Lightness factors in material selection and strength calculations of aircraft structures" (in Polish), XIV Conference Mechanics in Aeronautics, Kazimierz Dolny 24 - 27 May 2010, proceedings PTMTS ML-XIV 2010, vol. 2, pp. 583 - 596.

[2] Verein Deutscher Ingenieure: „Dimensionieren von Bauteilen as GFK” (Glasfaserstärkte Kunststoffe) - VDI 2013 Blatt 1, Düsseldorf 1973.

[3] Luftfahrt - Bundesamt : Vorläufige Dimensionierungswerte für Holme von Segelflugzeugen und Motorseglern, Stand: 20. August 1981

[4] Rodzewicz M.: Experimental study of lightness factors and loading abilities of sandwich structures. + Technical Soaring Vol. 35 No 4, pp 101 - 107, 2011.

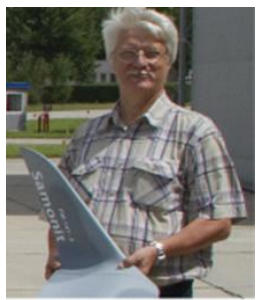

Dr hab.inz. Miroslaw Rodzewicz zatrudniony jest na stanowisku profesora $w$ Instytucie Techniki Lotniczej $i$ Mechaniki Stosowanej Wydzialu Mechanicznego Energetyki $i$ Lotnictwa w Politechnice Warszawskiej. Ukończyt Wydz. MEiL w 1978r. Również na tym wydziale obronit rozprawe doktorka (1993 r.) $i$ rozprawe habilitacyjna (2009 r.). Glównym obszarem zainteresowań jest mechanika eksperymentalna, technologia konstrukcji kompozytowych, badania statyczne $i$ badania zmęczeniowe kompozytowych struktur lotniczych, badania $w$ locie wyznaczanie spektrów obciązeń, a także projektowanie, budowa i testy samolotów bezzałogowych, a także ich aplikacja (Udziat 50\%).

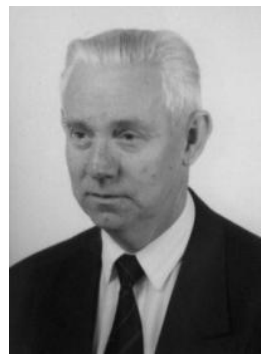

Prof. dr hab. inz. Jerzy Lewitowicz. Absolwent WAT - lotnictwo $i \quad$ UW fizyka jądrowa. Główne zainteresowania naukowe: technika wojskowa, kosmiczna, budowa $i$ eksploatacja samolotów i śmigłowców. Posiada ponad 60. letni staż naukowy $i$ dydaktyczny w Instytucie Technicznym Wojsk Lotniczych i na Politechnice Warszawskiej. Wieloletni członek SIMP, AIAA, ICAS, trzech komitetów Polskiej Akademii Nauk: Fizyki, Budowy Maszyn, Badań Kosmicznych i Satelitarnych. W autor ponad 400 publikacji naukowych; autor lub współautor 25 ksiażek, 27 wynalazków, ponad 450 opinii $i$ recenzji naukowych, uczestnik ponad 120 konferencji naukowych. Laureat wielu nagród naukowych w tym Mistrza Techniki Polskiej, rektora PW, „Błękitne Skrzydta”, MON, MEN., Min. Transp. Laureat nagrody TECHNICUS 2012 (Udziat 50\%). 